\title{
COVID-19's Impact on Italian Urology
}

\author{
Francesco Esperto ${ }^{1}$, Rocco Papalia ${ }^{1}$, Ana María Autrán-Gómez ${ }^{2}$, Roberto M. Scarpa ${ }^{1}$ \\ ${ }^{1}$ Department of Urology, Campus Bio-medico, University of Rome, Rome, Italy; ${ }^{2}$ Department of Urology \\ University Hospital Fundación Jiménez Díaz, Madrid, Spain
}

\section{ABSTRACT}

The COVID-19 pandemic has impacted our lives, our habits and our healthcare system. Italy is one of the countries affected first and more aggressively from the outbreak. Our rapidity has been guide for other healthcare systems from around the World. We describe the impact of COVID-19 on Urology, how the Urological scientific community responded to the emergency and our experience in a high-volume Roman University hospital. The aim of our work is to share our experience providing suggestions for other global hospitals on how to manage the COVID-19 emergency.

\section{ARTICLE INFO}

Francesco Esperto

http://orcid.org/0000-0002-0108-1864

Keywords:

COVID-19 [Supplementary

Concept]; Urology; Pandemics

Int Braz J Urol. 2020; 46 (Suppl 1): 26-33

Submitted for publication:

April 25, 2020

Accepted after revision:

May 10, 2020

Published as Ahead of Print: June 05, 2020

\section{EPIDEMIOLOGY}

The severe acute respiratory syndrome coronavirus 2 (SARS-CoV-2) was first identified in Wuhan, Hubei Province, China, in December 2019 (1). The disease has been termed COVID-19 and on March 11 ${ }^{\text {th }}$ 2020, The World Health Organization (WHO) declared it as a pandemic (2). On April 21 2 st $2,585,468$ COVID-19 positive cases and 178,854 deaths have been confirmed worldwide. The United States, Spain and Italy were the most affected countries with 825,306, 208,389 and 183,957 positive cases respectively (3).

\section{ITALY}

COVID-19 was first detected in Italy on January $30^{\text {th }}$, and the Italian government immediately declared the state of emergency. A COVID-19 task Force and a Special Commissioner for the Emergency were appointed. On February $23^{\text {th }}$, a ban was put on entry and exit in the municipalities where outbreaks occurred, and public events were suspended. National lock down was officially announced on March $9^{\text {th }}(4)$. The number of cases increased since the first case and peaked in mid-March (Figure-1) (5). 
Figure 1 - The outbreak evolution curve of confirmed COVID-19 new cases in Italy from Feb 2 to April 12 (5).

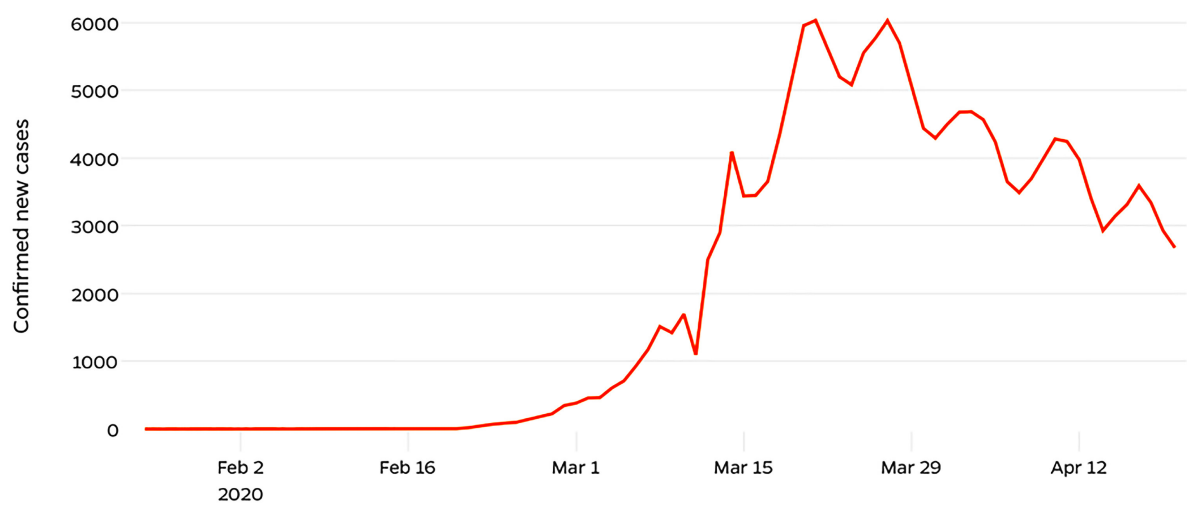

On April $29^{\text {th }}$ the number of COVID-19 associated deaths was 26,977 . A total of 17,997 healthcare workers were tested positive for COVID-19 (median age 48 years, 32\% male), which accounted for $10.7 \%$ of the total number of reported cases. The high transmission potential of the virus in the healthcare sector was evident (Figure-2) (6). Overall, 79,370 cases were male $(50.0 \%)$ and the median age amongst both genders was 62 years (range 0-100). In the age groups 0-9, 10-19, 60-69 and 70-79 years, a greater number of male cases compared with female were observed. There was an increase in lethality with increasing age of cases. Lethality was higher in male subjects in all age groups, except for the age group $>90$ years. In $31.1 \%$ of the reported cases, at least one co-morbidity was identified (cardiovascular, respiratory, diabetes, immune deficiencies, metabolic, oncological, obesity, kidney and other chronic pathologies) (6). Presenting symptoms of COVID-19 patients included fever (75\%), dyspnea (72\%), cough (38\%), diarrhea (6\%), hemoptysis (1\%). Overall, $60.7 \%$ of COVID-19 deaths were associated with 3 or more pre-existing diseases (4). The distribution of COVID-19 cases varies within the country. The north is much more affected and is reflected on the mortality rate (Figure-3) (3).

At the $28^{\text {th }}$ of April the most affected regions were Lombardy, Piedmont, Emilia-Romagna, Veneto, Tuscany and Liguria with an amount of total cases detected of 74348, 25450, 24914, 17708, 9231, 7772 respectively. The mortality rate was the following:
18.3 \% in Lombardy, $11.5 \%$ in Piedmont, $13.9 \%$ in Emilia Romagna, 7.95 \% in Veneto, 8.8 \% in Tuscany, $14.7 \%$ in Liguria.

The less affected regions were Calabria, Basilicata and Molise with a mortality rate of 7.7 \%, $6.8 \%, 7.1 \%$ respectively. Lazio with 6467 cases detected had a mortality rate of $6.4 \%$.

Intensive care units (ICUs) filled up quickly with COVID-19 patients and became stretched to accommodate non-COVID-19 patients who required critical care. In Lombardy Grasselli et al. described a mortality rate of $26 \%$ in ICUs as of March 25, 2020 (7). The initial lack of personal protective equipment (PPE) and swab testing led to a rapid spread. Healthcare professionals were being infected, reducing the number of healthcare workers (HWs) available to manage the emergency. However, the situation was different in less affected regions where there was more time to prepare and organize resources and HWs to manage the pandemic.

\section{MEASURES}

Members of the RUN (Research Urology Network) group provided guidance on the management of urological patients during the COVID-19 era. They suggested treatment for urgent or emergent urological conditions only. Factors affecting the categorization of procedures included the need for postoperative intensive care, need for blood transfusion or 
Figure 2 - Integrated surveillance of COVID-19 in Italy (6).

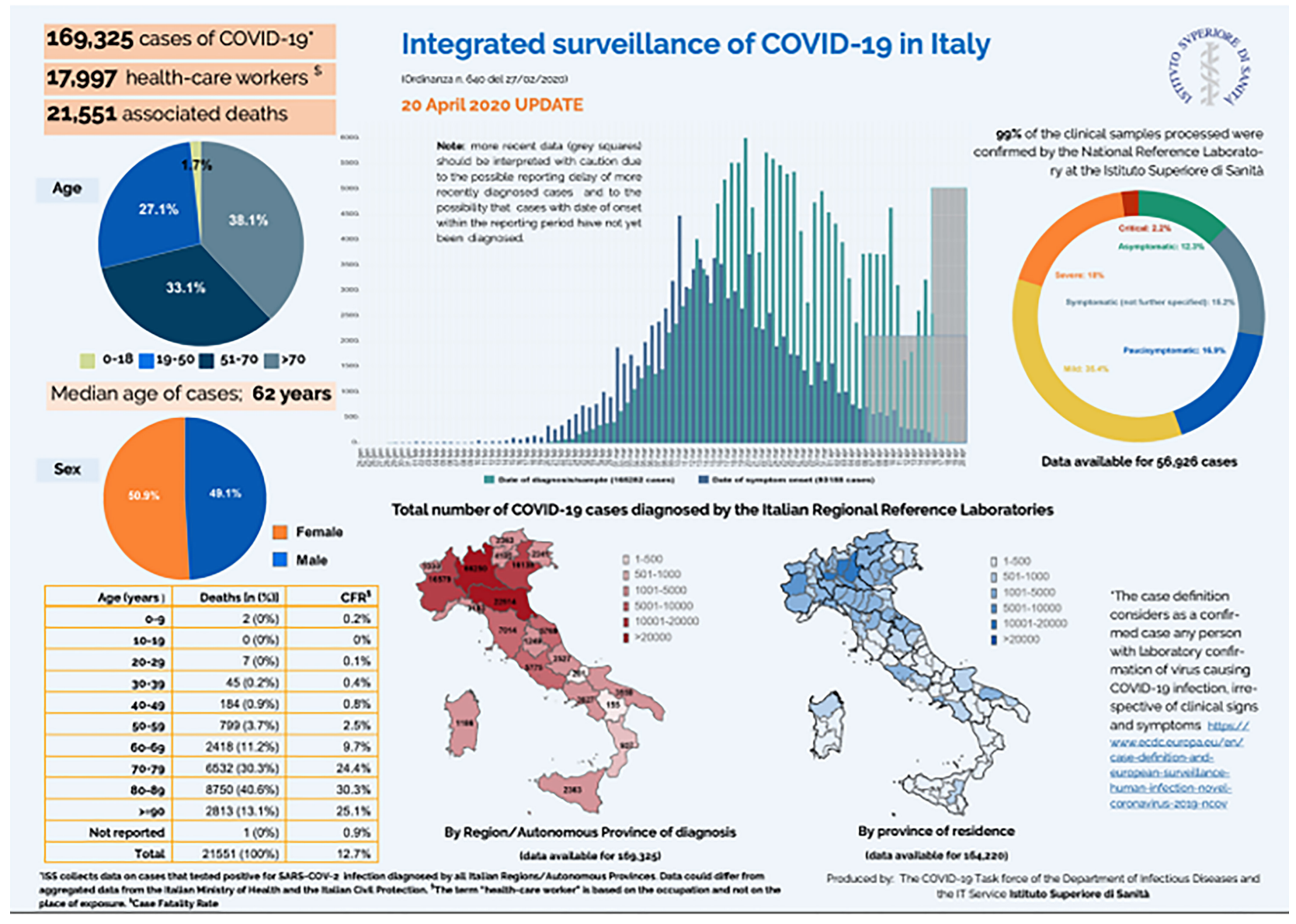

other blood products, cardiovascular, respiratory or infective comorbidities, and the need for psychophysical support. Indications in postponing up to six months prostate biopsies, flexible cystoscopies, replacements of ureteral stents and nephrostomy tubes, intravesical therapy for low and intermediate risk bladder cancers have been provided (Table-1) (8).

The admission pathway included pre-admission telephone triage, nasopharyngeal swabs, PPE, strict rules in the operating room (9). Ribal et al. produced dedicated European Associations of Urology (EAU) guidelines on the management of Urological patients during the COVID-19 outbreak (10). Despite strong efforts in trying to prioritize oncological and urgent procedures, the burden of oncological patients on waiting list is increasing. Campi et al. des- cribed the progressive reduction in all elective's procedures in three high volume Urology centers in Italy (11).

Impact on training

Resident's programs in Europe and in Italy are just harassed from a lack of adequate academic and surgical training (12-15) and it is known how its associated frustration may lead to burnout (16). Several papers described a global slowdown of Urology residence program during the pandemic (17-19). Social Media and smart learning implementation have been proposed as valid tools to supply scientific knowledge during this scenario $(20,21)$. Our group asked "what should be the role of residents during a pandemic?'. On calling the Hippocrates statement (Afhprism 1,1) "O ßíos $\beta \rho \alpha \chi u ́ \varsigma, \dot{\eta} \delta \grave{\varepsilon} \tau \dot{\varepsilon} \chi v \eta \mu \alpha \kappa \rho \eta ́$, ó $\delta \grave{\varepsilon} \kappa \alpha \iota \rho \grave{\varsigma}$ ỏ $\xi u ́ s, \dot{\eta} \delta \grave{\varepsilon}$ 
Figure 3 - Distribution of COVID-19 cases in Italy (3).

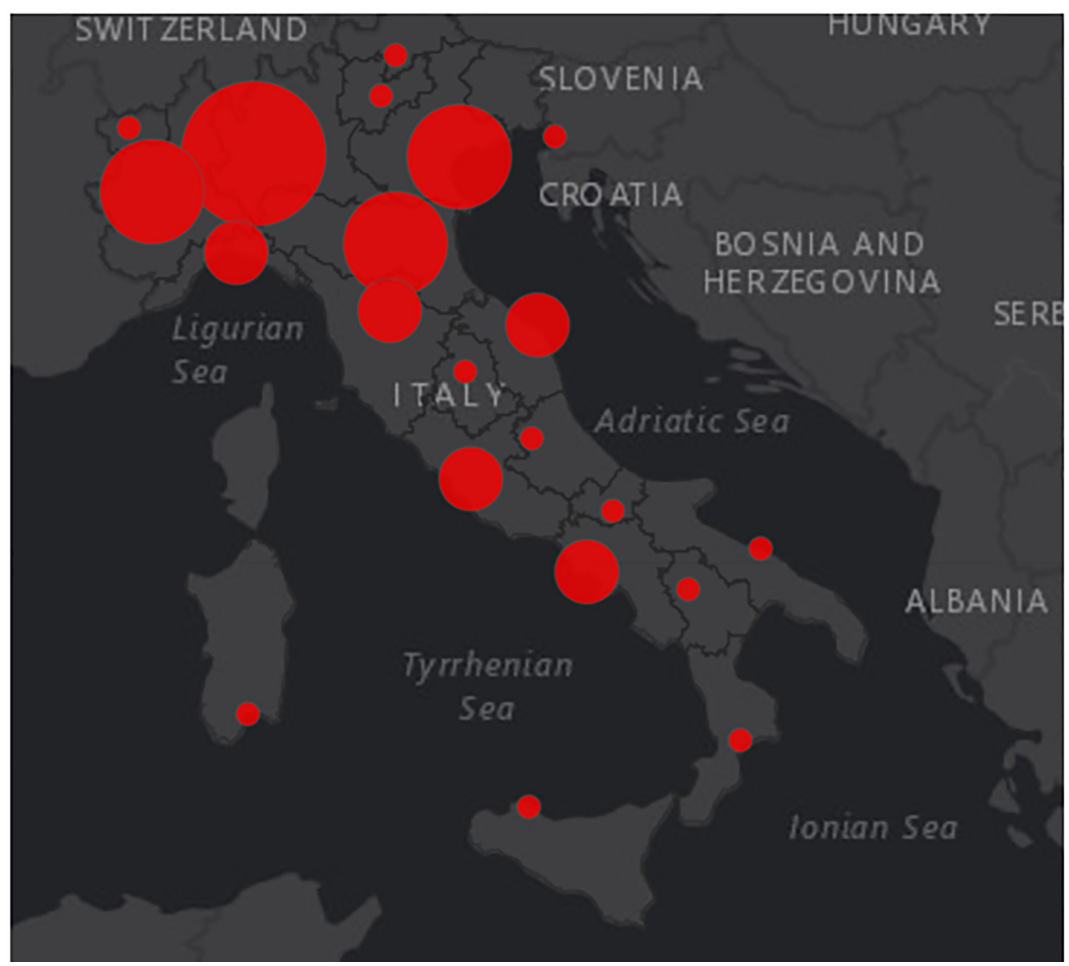

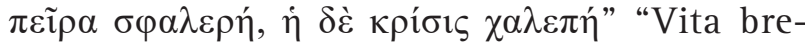
vis, ars longa, occasion praeceps, experimentum periculosum, iudicium difficile", we think residents should play an active role alongside the specialist by exploiting the pandemic as an unrepeatable opportunity from which to learn upon (22). In general, the COVID-19 emergency is a highly dynamic situation and the burden on the healthcare system varies daily according to the geographical region.

\section{Our Experience}

Campus Bio-Medico University is a high-volume university Hospital in Rome. It has no Accident and Emergency (A and E) Department and currently is COVID-19 free. We continue to operate on oncological and urgent patients with safety precautions. Information about the virus, local policies, patients' access to the hospital, surgery protocols and individual protection have been provided to all HWs (Table-2). Every 8 hours a FFP2 mask is made available at the main entrance of the hospital. An open $\mathrm{Ou}$ tpatient COVID-19 Clinic (composed of 2 senior and 3 junior Internal Medicine Consultants) for HWs has been established to review those with symptoms or have been in close contact with a positive or suspect COVID-19 patient.

Access to the Hospital is regulated through telephone triage to rule out any symptoms or suspicion of COVID-19. In suspected cases, responsible physicians would call to clarify. In non-suspected cases, patients could go for hospital admission as pre-planned. In suspected cases, patients are instructed to stay at home and call their GP for further advice. The access to the hospital is allowed from a unique entrance with security check.

A surgical facemask and hand hygiene with $60 \%$ alcoholic solution are provided to everyone at the entrance. Temperature is checked through a thermoscanner, symptoms are checked and reason for admission is evaluated. If no issues are encountered during this phase, patient can ac- 
Table 1 - Factors potentially affecting the choice of the different urological procedures during COVID- 19 pandemic (8).

\begin{tabular}{|c|c|c|}
\hline Procedure & Indication for the emergency phase & Note \\
\hline Prostate biopsy & Postpone & $\begin{array}{l}\text { Reconsider performing prostate biopsy } \\
\text { in patients with high clinical suspicion of } \\
\text { prostate cancer if the emergency phase } \\
\text { should prolong }\end{array}$ \\
\hline Flexible cystoscopy & Postpone & $\begin{array}{l}\text { Reconsider performing cystoscopy in } \\
\text { patients with high risk bladder cancer if } \\
\text { the emergency phase should prolong }\end{array}$ \\
\hline $\begin{array}{l}\text { Replacement of ureteral stents and } \\
\text { nephrostomy tube }\end{array}$ & Postpone up to 6 months & \\
\hline $\begin{array}{l}\text { Intravesical therapy for high risk bladder } \\
\text { cancer }\end{array}$ & Do not postpone & \\
\hline $\begin{array}{l}\text { Intravesical therapy for low or } \\
\text { intermediate risk bladder cancer }\end{array}$ & Postpone & \\
\hline
\end{tabular}

cess the hospital. If any doubts are raised during the admission check, the responsible physician would review the case and decide whether to proceed with pre-planned admission or to refer to a dedicated COVID team.

We have detected three positive patients (in droplet isolation inside the hospital from the beginning of their admission) who have been transferred to COVID-19 centers within 48 hours. All the healthcare staff who had been in contact with them have been swabbed twice with negative results, showing the efficacy of the policy undertaken.

Visitors are allowed to access the hospital for a limited span of time (1 hour) and only one person per patient are allowed to visit after strict security checks performed at the main entrance.

We developed telemedicine protocols for outpatient's clinic and arranged virtual multidis- ciplinary meetings for oncological patients. Our surgical activity increased in volume, performing exclusively elective oncological and urgent operations. All patients treated have been called two weeks after discharge and none have declared any symptoms of COVID-19.

\section{CONCLUSION}

COVID-19 emergency is a highly dynamic situation and the burden on the healthcare system varies daily according to the geographical region. Through meticulous hospital instructions, prompt adoption of PPE, controlled access to the hospital, and prompt management of suspected/positive cases, we were able to maintain a COVID-19 free hospital and to continue our surgical activities during the pandemic. 
Table 2 - Summary of the COVID-19 task force actions regarding PPE of Health workers (HWs).

\begin{tabular}{|c|c|c|c|c|c|c|c|}
\hline \multicolumn{2}{|c|}{ Front office staff working } & \multicolumn{5}{|c|}{ Healthcare personnel in contact with patients } & \multirow{2}{*}{$\begin{array}{l}\text { Laboratory } \\
\text { staff in } \\
\text { contact with } \\
\text { biological } \\
\text { samples }\end{array}$} \\
\hline $\begin{array}{l}\text { At station in } \\
\text { direct contact } \\
\text { with patients }\end{array}$ & $\begin{array}{l}\text { At station } \\
\text { with } \\
\text { protective } \\
\text { glass }\end{array}$ & $\begin{array}{l}\text { In contact } \\
\text { with a } \\
\text { suspected or } \\
\text { confirmed } \\
\text { case of } \\
\text { COVID-19 }\end{array}$ & $\begin{array}{c}\text { In contact } \\
\text { with a patient } \\
\text { who presents } \\
\text { symptoms of } \\
\text { fever and / or } \\
\text { cold and / or } \\
\text { cough }\end{array}$ & $\begin{array}{l}\text { Performing } \\
\text { endoscopic } \\
\text { procedures }\end{array}$ & $\begin{array}{c}\text { Assigned } \\
\text { to take a } \\
\text { biological } \\
\text { sample for } \\
\text { COVID-19 + } \\
\text { patient }\end{array}$ & $\begin{array}{l}\text { Anesthesiologists } \\
\text { performing } \\
\text { intubation }\end{array}$ & \\
\hline $\begin{array}{l}\text { frequent } \\
\text { hand hygiene } \\
\text { by using } 60 \\
\% \text { alcohol } \\
\text { solution }\end{array}$ & $\begin{array}{l}\text { frequent } \\
\text { hand } \\
\text { hygiene by } \\
\text { using } 60 \\
\% \text { alcohol } \\
\text { solution }\end{array}$ & $\begin{array}{l}\text { FFP2 filtering } \\
\text { mask (use } \\
\text { FFP3 only } \\
\text { for the } \\
\text { procedures } \\
\text { that generate } \\
\text { aerosols) }\end{array}$ & $\begin{array}{l}\text { FFP2 filtering } \\
\text { mask (use } \\
\text { FFP3 only } \\
\text { for the } \\
\text { procedures } \\
\text { that generate } \\
\text { aerosols) }\end{array}$ & $\begin{array}{l}\text { FFP3 filtering } \\
\text { masks }\end{array}$ & $\begin{array}{l}\text { FFP3 filtering } \\
\text { mask }\end{array}$ & $\begin{array}{l}\text { FFP3 filtering } \\
\text { mask }\end{array}$ & $\begin{array}{l}\text { FFP3 } \\
\text { filtering } \\
\text { mask }\end{array}$ \\
\hline $\begin{array}{l}\text { wear the } \\
\text { FFP2 filtering } \\
\text { mask during } \\
\text { the entire } \\
\text { work shift }\end{array}$ & l & $\begin{array}{l}\text { goggles } \\
\text { or visors } \\
\text { to protect } \\
\text { eyes from } \\
\text { biological } \\
\text { liquids } \\
\text { 'splashes }\end{array}$ & $\begin{array}{l}\text { goggles } \\
\text { or visors } \\
\text { to protect } \\
\text { eyes from } \\
\text { biological } \\
\text { liquids } \\
\text { 'splashes }\end{array}$ & $\begin{array}{l}\text { goggles } \\
\text { or visors } \\
\text { to protect } \\
\text { eyes from } \\
\text { biological } \\
\text { liquids } \\
\text { 'splashes }\end{array}$ & $\begin{array}{l}\text { goggles } \\
\text { or visors } \\
\text { to protect } \\
\text { eyes from } \\
\text { biological } \\
\text { liquids } \\
\text { 'splashes }\end{array}$ & $\begin{array}{l}\text { goggles or visors } \\
\text { to protect eyes } \\
\text { from biological } \\
\text { liquids 'splashes }\end{array}$ & $\begin{array}{l}\text { goggles } \\
\text { or visors } \\
\text { to protect } \\
\text { eyes from } \\
\text { biological } \\
\text { liquids } \\
\text { 'splashes }\end{array}$ \\
\hline $\begin{array}{l}\text { wear } \\
\text { protective } \\
\text { glasses } \\
\text { from liquids } \\
\text { splashes } \\
\text { during the } \\
\text { entire work } \\
\text { shift }\end{array}$ & l & $\begin{array}{l}\text { water } \\
\text { repellent PPE } \\
\text { coat }\end{array}$ & I & $\begin{array}{l}\text { water } \\
\text { repellent PPE } \\
\text { coat }\end{array}$ & $\begin{array}{l}\text { water } \\
\text { repellent PPE } \\
\text { coat }\end{array}$ & $\begin{array}{l}\text { water repellent } \\
\text { PPE coat }\end{array}$ & $\begin{array}{l}\text { water } \\
\text { repellent } \\
\text { PPE coat }\end{array}$ \\
\hline $\begin{array}{l}\text { provide a } \\
\text { surgical } \\
\text { mask, } \\
\text { supplied at } \\
\text { the desk, to } \\
\text { be worn by } \\
\text { the patient } \\
\text { with visible } \\
\text { respiratory } \\
\text { symptoms }\end{array}$ & $\begin{array}{l}\text { provide a } \\
\text { surgical } \\
\text { mask, } \\
\text { supplied } \\
\text { at the } \\
\text { desk, to be } \\
\text { worn by } \\
\text { the patient } \\
\text { with visible } \\
\text { respiratory } \\
\text { symptoms }\end{array}$ & $\begin{array}{l}\text { double } \\
\text { gloves }\end{array}$ & gloves & gloves & $\begin{array}{l}\text { double } \\
\text { gloves }\end{array}$ & double gloves & $\begin{array}{l}\text { double } \\
\text { gloves }\end{array}$ \\
\hline
\end{tabular}




\section{CONFLICT OF INTEREST}

None declared.

\section{REFERENCES}

1. WHO. Director-General's opening remarks at the media briefing on COVID-19 on 21 February 2020. World Health Organization. Available at. < https://www.who. int/dg/speeches/detail/who-director-general-s-openingremarks-at-the-media-briefing-on-covid-19-on-21february-2020>.

2. WHO. Timeline - COVID-19. Available at. <https://www. who.int/news-room/detail/08-04-2020-who-timeline--covid-19>.

3. COVID-19 Dashboard by the Center for Systems Science and Engineering (CSSE) at Johns Hopkins University (JHU). Johns Hopkins University \& Medicine. Available at. <https://coronavirus.jhu.edu/map.html>

4. Covid-19 - Situazione in Italia. Ministero della Salute 2020. Available at. <http://www.salute.gov.it/portale/ nuovocoronavirus/dettaglioContenutiNuovoCoronavirus. jsp?area $=$ nuovoCoronavirus \&id $=5351$ \&lingua $=$ italiano $\&$ menu=vuoto $>$.

5. New Cases of COVID-19 In World Countries. Available at $<$ https://coronavirus.jhu.edu/data/new-cases>.

6. Integrated surveillance of COVID-19 in Italy. Istituto Superiore di Sanità. Available at. <www.epicentro.iss.it/ en/coronavirus/bollettino/Infografica_20aprile\%20ENG. $p d f>$.

7. Grasselli G, Zangrillo A, Zanella A, Antonelli M, Cabrini L, Castelli A, et al. Baseline Characteristics and Outcomes of 1591 Patients Infected With SARS-CoV-2 Admitted to ICUs of the Lombardy Region, Italy. JAMA. 2020; 323:1574-81.

8. Ficarra V, Novara G, Abrate A, Bartoletti R, Crestani A, De Nunzio $C$, et al. Urology practice during COVID-19 pandemic. Minerva Urol Nefrol. 2020. Epub ahead of print.

9. Simonato A, Giannarini G, Abrate A, Bartoletti R, Crestani $A$, De Nunzio $C$, et al. Pathways for urology patients during the COVID-19 pandemic. Minerva Urol Nefrol. 2020. Epub ahead of print.
10. Ribal MJ, Cornford P, Briganti A, Knoll T, Gravas S, Babjuk $\mathrm{M}$, et al. European Association of Urology Guidelines Office Rapid Reaction Group: An Organisation-wide Collaborative Effort to Adapt the European Association of Urology Guidelines Recommendations to the Coronavirus Disease 2019 Era. Eur Urol. 2020:S0302-2838; 303249. Available at. <https://uroweb.org/wp-content/uploads/ EAU-Guidelines-Office-Rapid-Reaction-Group-Anorganisation-wide-collaborative-effort-to-adapt-theEAU-guidelines-recommendations-to-the-COVID-19-era. $p d f>$.

11. Campi R, Amparore D, Capitanio U, Checcucci E, Salonia A, Fiori $\mathrm{C}$, et al. Assessing the Burden of Nondeferrable Major Uro-oncologic Surgery to Guide Prioritisation Strategies During the COVID-19 Pandemic: Insights from Three Italian High-volume Referral Centres. Eur Urol. 2020:S0302-2838; 30229-3.

12. Carrion DM, Gómez Rivas J, Esperto F, Patruno G, Vasquez $\mathrm{JL}$. Current status of urological training in Europe. Arch Esp Urol. 2018; 71:11-7.

13. Carrion DM, Rodriguez-Socarrás ME, Mantica G, Esperto F, Cebulla A, Duijvesz D, et al. Current status of urology surgical training in Europe: an ESRU-ESU-ESUT collaborative study. World J Urol. 2020; 38:239-46.

14. Cocci A, Patruno G, Gandaglia G, Rizzo M, Esperto F, Parnanzini $D$, et al. Urology Residency Training in Italy: Results of the First National Survey. Eur Urol Focus. 2018; 4:280-7.

15. Carrion DM, Rodríguez-Socarrás ME, Mantica G, Pang $\mathrm{KH}$, Esperto $\mathrm{F}$, Mattigk A, et al. Interest and involvement of European urology residents in academic and research activities. An ESRU-ESU-ESUT collaborative study. Minerva Urol Nefrol. 2020. Epub ahead of print.

16. Marchalik D, C Goldman C, F L Carvalho F, Talso M, H Lynch J, Esperto F, et al. Resident burnout in USA and European urology residents: an international concern. BJU Int. 2019; 124:349-56.

17. Porpiglia F, Checcucci E, Amparore D, Verri P, Campi R, Claps $F$, et al. Slowdown of urology residents' learning curve during the COVID-19 emergency. BJU Int. 2020. Epub ahead of print

18. Amparore D, Claps F, Cacciamani GE, Esperto F, Fiori C, Liguori G, et al. Impact of the COVID-19 pandemic on urology residency training in Italy. Minerva Urol Nefrol. 2020. Epub ahead of print 
19. Pang KH, Carrion DM, Rivas JG, Mantica G, Mattigk A, Pradere $B$, et al. The Impact of COVID-19 on European Health Care and Urology Trainees. Eur Urol. 2020: S0302-2838;30305-5.

20. Rivas JG, Socarras MR, Patruno G, Uvin P, Esperto F, Dinis PJ, et al. Perceived Role of Social Media in Urologic Knowledge Acquisition Among Young Urologists: A European Survey. Eur Urol Focus. 2018; 4:768-73.
21. Gómez Rivas J, Carrion DM, Tortolero L, Veneziano D, Esperto F, Greco F, et al. Scientific social media, a new way to expand knowledge. What do urologists need to know? Actas Urol Esp. 2019; 43:269-76.

22. Esperto F, Papalia R, Pang KH, Cataldo R, Scarpa RM. What is the role of residents during a pandemic? Minerva Urol Nefrol 2020;72:000-000. Epub ahead of print.

Correspondence address:

Francesco Esperto, MD

Department of Urology, Campus Bio-medico, University of Rome,

Via Alvaro del Portillo, 200, Rome, 00128, Italy. E-mail: francescoesperto@gmail.com 